\title{
Temperature effect on biochar properties from slow pyrolysis of coconut flesh waste
}

\author{
Nurhidayah Mohamed Noor*, Adilah Shariff, Nurhayati Abdullah, Nur Syairah Mohamad Aziz \\ Energy Study Laboratory, School of Physics, Universiti Sains Malaysia, Minden 11800, Penang, Malaysia
}

* Corresponding author:nurhidayah_energystudy@yahoo.com

\section{Article history}

Received 3 February 2018

Revised 8 June 2018

Accepted 3 July 2018

Published Online 14 April 2019

\begin{abstract}
The aim of this study was to investigate the effect of pyrolysis temperature on the biochar yield and properties via slow pyrolysis of coconut flesh waste. The temperature used in the slow pyrolysis experiment was varied between $350^{\circ} \mathrm{C}$ to $600^{\circ} \mathrm{C}$ at a constant heating rate of $5^{\circ} \mathrm{C} / \mathrm{min}$. The results indicated that higher pyrolysis temperature could reduce the percentage of biochar yield. The increment of pyrolysis temperature from $350^{\circ} \mathrm{C}$ to $600^{\circ} \mathrm{C}$ would reduce the biochar yield from 23.54 wt.\% to $13.97 \mathrm{wt} . \%$. The effect of pyrolysis temperature was also significant on the composition and physical properties of biochar yield. The physicochemical properties of biochar were identified by proximate, elemental, heating value, SEM images and BET surface area analyses. The increment of pyrolysis temperature from $350^{\circ} \mathrm{C}$ to $600^{\circ} \mathrm{C}$ increased the ash content of biochar from $4.63 \mathrm{wt} . \%$ to $8.19 \mathrm{wt} . \%$, the fixed carbon content from $45.20 \mathrm{wt} . \%$ to $79.09 \mathrm{wt} . \%$ and carbon content from 72.70 wt. $\%$ to 83.25 wt.\%. Meanwhile the volatile matter and oxygen content of biochar were decreased from 50.17 wt. $\%$ to 12.71 wt.\% and 13.86 wt.\% to 10.99 wt.\%, respectively as the pyrolysis temperature was increased from $350^{\circ} \mathrm{C}$ to $600^{\circ} \mathrm{C}$. The increment of pyrolysis temperature from $350^{\circ} \mathrm{C}$ to $600^{\circ} \mathrm{C}$ increased the surface area of biochar by 8 fold from $0.3971 \mathrm{~m}^{2} / \mathrm{g}$ to $3.4486 \mathrm{~m}^{2} / \mathrm{g}$. Meanwhile, the higher heating value of biochar was decreased from $33.95 \mathrm{MJ} / \mathrm{kg}$ to $27.49 \mathrm{MJ} / \mathrm{kg}$ as the pyrolysis temperature was increased from $350^{\circ} \mathrm{C}$ to $600^{\circ} \mathrm{C}$.
\end{abstract}

Keywords: Biochar, pyrolysis, temperature, coconut waste, biomass

C 2019 Penerbit UTM Press. All rights reserved

\section{INTRODUCTION}

Coconut or its scientific name as Cocos nucifera $L$. is the most consumed fruit in Malaysia. The Department of Statistics Malaysia (DOSM) reported that the average coconut consumption for each person in Malaysia is 17.30 kilogrammes per year (DOSM, 2016). The production of coconuts in Malaysia is increased yearly due to high demand on the coconut product in the form of coconut milk and coconut oil. The coconut production in year 2014 is 653,000 tons which increased by $18.73 \%$, compared to year 2010 (APCC, 2017). This considerable production is coupled with abundant of coconut wastes such as the coconut shell, coconut husk and coconut flesh waste (CFW) (Raghavarao et al., 2008) . CFW is a by-product after the coconut milk or coconut oil was extracted from the grated coconut flesh. In year 2010, estimated 78,000 metric tons of CFW were generated from both coconut oil and coconut milk industries in Malaysia (Sulaiman et al., 2013). CFW is usually used as feed for animals such as cows, pigs and poultry, but mostly it was left to decompose on the field as waste residue (Sulaiman, R., \& Aroua, 2014; Vetayasuporn, 2007). There are researches done to utilize the CFW as a dietary fibre (Ng et al., 2010; Raghavarao et al., 2008) and for bio-diesel production (Sulaiman et al., 2014). One of alternative and more sustainable ways to reduce and utilize the CFW is by conversion into biochar via pyrolysis process.

Pyrolysis can be described as the thermal decomposition of biomass in the absence or restricted oxygen to obtain bio-oil, biochar and gaseous product (Balat et al., 2009; Verma et al., 2012). Pyrolysis process offers a great opportunity from the sustainable development point of view since it allows the use of a wide variety of materials as the feedstock and produces low emission greenhouse gases, compared to the other technologies that are used in the process of incineration (Verma et al., 2012; Zajec, 2009). There are a few types of pyrolysis such as fast pyrolysis and slow pyrolysis. The different types of pyrolysis process are distinguished by the operating conditions such as the temperature, heating rate and the residence time (Mohan et al., 2014). The operating conditions can be optimized to maximize the production of bio-oil, biochar and gaseous product. According to Odesola and Owoseni (2010), fast pyrolysis process which could be done in seconds would yield relatively more bio-oil while slow pyrolysis could produce more biochar but it took hours to complete. Fast pyrolysis produced $60 \%$ of bio-oil, $20 \%$ of biochar and $20 \%$ of syngas, whereas slow pyrolysis could be optimized to yield significantly more biochar up to $50 \%$.

Biochar is a solid material obtained from the pyrolysis of plant biomass or agricultural waste $(\mathrm{Wu}$ et al., 2016). There are many evidences that suggested biochar as a potential tool to mitigate the world's climate change. One of the main reason is because of its carbon component that has great longevity and highly recalcitrant (Lehmann et al., 2006). For example, the residence time for wood biochar was reported to be in the range from 100 years to 1,000 years (Verheijen et al., 2009). According to Hunt et al. (2010), by converting biomass into biochar, many of its carbon content would become 'fixed' into a more stable form. The exothermic process during the biochar production via pyrolysis precipitated carbon dioxide onto the biochar surfaces (Lehmann, 2007). The biochar production can also reduce the emission of greenhouse gases (GHG) 
especially carbon dioxide that mainly caused the climate change (IBI, 2016). Lehmann (2007) reported that during the pyrolysis process, biochar was able to scrub the carbon dioxide, nitrous oxide and sulphur oxide from the flue gas and thus, decreasing those GHG emissions to the air.

There are many biochar applications that varied according to the biochar physicochemical characteristics. For example, biochar with high heating value can be better used for solid fuel production such as briquette (Bazargan et al., 2014) whereas those with high surface area may function as the soil amendment to improve fertility (Lehmann $e$ al., 2011). Biochar quality and quantity are depended on the production conditions and types of the raw biomass feedstock. One of the main factors that influenced the biochar properties is the pyrolysis temperature because the fundamental physical changes of biochar are all depended on the pyrolysis temperature (Downie et al., 2009). Jahirul et al. (2012) summarized the products created at different ranges of pyrolysis temperature. They concluded that biochar yield could be maximized at a low pyrolysis temperature and heating rate process where the range of temperature might be varied with the type of feedstock. Zhao et al. (2014) suggested that generally the pyrolysis temperature for biochar production was lower than $500^{\circ} \mathrm{C}$ while higher pyrolysis temperature at $650^{\circ} \mathrm{C}$ could minimize the effects of pyrolysis kinetics, causing in incomplete biochar formation.

Practically, no report is available in the literature regarding the utilization of CFW for biochar production. Only very little is actually known about the physicochemical of CFW and the potential of this coconut waste as the feedstock for pyrolysis process. Determination on how the pyrolysis condition can relate to the biochar properties will be highly beneficial to identify its appropriate applications. Therefore, this study was aimed to find the effect of pyrolysis temperature on the biochar yield and its properties.

\section{EXPERIMENTAL}

\section{Characterization of coconut flesh waste}

The CFW feedstock as shown in Fig. 1 was obtained from a coconut milk supplier in Penang, Malaysia. The pre-drying treatment was conducted on the feedstock using a conventional oven at the temperature of $60^{\circ} \mathrm{C}$ and continued until its weight was remained constant. This step was important to give off non-flammable components such as carbon dioxide and water for more efficient heating process later.

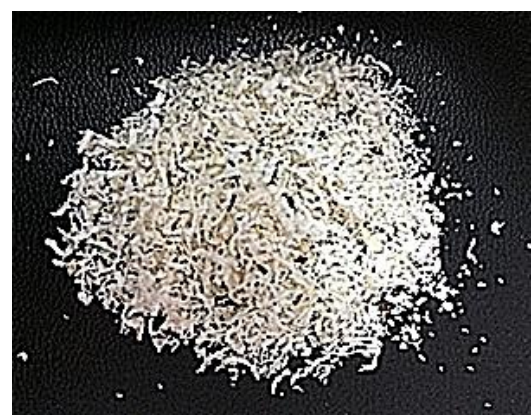

Fig. 1 Coconut flesh waste.

Characteristics studies on the feedstock were important to express its suitability for thermochemical conversion. Hence, the proximate analysis was performed on the pre-dried CFW samples, according to the ASTM International Standard Test Method E1756-01, E872-82 and E1755-01 to determine the moisture, volatile and ash content, respectively. The fixed carbon content was calculated using Eq. (1).

$$
\text { Fixed carbon }=100-(\text { Volatile matter }+ \text { Ash })
$$

Perkin Elmer 2400 elemental analyzer was used to determine the carbon $(\mathrm{C})$, hydrogen $(\mathrm{H})$, nitrogen $(\mathrm{N})$ and sulphur $(\mathrm{S})$ content. The oxygen $(\mathrm{O})$ content was calculated according to Eq. (2). Results from both proximate and elemental analyses were presented in weight percentage on dry basis (wt.\%).

$$
O=100-(C+H+N+S)
$$

The high heating value of the pre-dried CFW was determined using IKA calorimeter model C200. Meanwhile, the microstructure of the pre-dried CFW was examined using a scanning electron microscope (SEM). SEM could highly magnify the image of the specimen and show its surface morphology and topography. The analysis was carried out using the JEOL system model JSM-6460 LV.

\section{Slow pyrolysis}

The slow pyrolysis set-up was shown in Fig. 2 which consisted of the pyrolyzing and the condensing parts. This experimental set-up was the upgraded version from the previous study by Noor et al. (2012). In this work, there was an additional of the nitrogen gas system. According to Deris et al. (2006), the nitrogen gas that purged into the pyrolyzer was used to sweep volatile and gaseous products into the condensing system and maintain the inert atmosphere in the pyrolyzer.

The feedstock was manually filled into the stainless steel pyrolyzer. About $100 \mathrm{~g}$ of feedstock was used for each pyrolysis run. The slow pyrolysis was conducted at six different temperatures that ranged from $350^{\circ} \mathrm{C}$ to $600^{\circ} \mathrm{C}$. The controlled pyrolysis parameters were the heating rate of $5^{\circ} \mathrm{C} / \mathrm{min}$ and the holding time of an hour. $0.5 \mathrm{~L} / \mathrm{hr}$ of nitrogen gas was purged into the pyrolyzer throughout the pyrolysis process.



Fig. 2 The schematic diagram of slow pyrolysis experimental set-up.

The weight of biochar was determined by weighing the pyrolyzer after each pyrolysis run. For each pyrolysis temperature, the average biochar yields from three pyrolysis runs were presented. The percentage of biochar yield was calculated using Eq. (3) and expressed in weight percent (wt.\%).

Biochar yield $=[$ Wt. of biochar $(g) /$ Wt of sample $(g)] \times 100$

The biochar products were kept neat within the sealed plastic container and placed inside the desiccator. Biochar produced in each experiment was characterized using the methods described below.

\section{Characterization of biochars}

The proximate analysis of the coconut flesh waste biochars (CFWB) was performed using the same ASTM method as the raw feedstock. ASTM International Standard Test Methods used were ASTM E1756-01, ASTM E872-82 and ASTM E1755-01 for determination of moisture, volatile and ash content, respectively. The fixed carbon content was calculated using Eq. (1). Meanwhile the elemental analysis of the biochars was determined using the Perkin Elmer 2400 elemental analyzer and the oxygen (O) content was calculated using Eq. (2). The heating value of CFWB was determined using IKA calorimeter model C200.

The surface morphologies of selected biochars were observed using JEOL system model JSM-6460 LV at magnification of 500 times. The result was compared with the raw feedstock. The surface area of the biochars was determined according to the Brunauer, Emmett and Teller (BET) theory. The analysis was done by using the Micromeritics accelerated surface area and porosimetry system model ASAP 2020. 


\section{RESULTS AND DISCUSSION}

\section{Composition of coconut flesh waste}

The properties of CFW feedstock were shown in Table 1. After the pre-drying treatment, the moisture content of the feedstock was 4.42 wt. $\%$. The value was acceptable for slow pyrolysis process because if the moisture content of the feedstock was too high, greater than $10 \mathrm{wt} . \%$, a large fraction of the generated heat would evaporate into water and reduce the effectiveness of the pyrolysis heating process (Vieweg, 1984).

Table 1 Properties of coconut flesh waste.

\begin{tabular}{lc}
\hline \multicolumn{1}{c}{ Characteristics } & Coconut flesh waste \\
\hline Proximate analysis, (wt.\%) & 4.42 \\
Moisture & 91.03 \\
Volatile matter & 1.05 \\
Ash & 7.92 \\
Fixed carbon & \\
Elemental analysis, (wt.\%) & \\
Carbon, C & 58.33 \\
Hydrogen, H & 14.33 \\
Nitrogen, N & 1.32 \\
Sulphur, S & 1.37 \\
Oxygen, O & 24.65 \\
High heating value, (MJ/kg) & 28.85 \\
\hline
\end{tabular}

The main criterion of biomass feedstock for pyrolysis process is high in volatile matter and heating value but low in ash and sulphur contents (Gheorghe et al., 2010). Table 1 showed that CFW was a suitable feedstock for pyrolysis process as it contained high percentages of volatile matter and heating value which were 91.03 wt. $\%$ and $28.85 \mathrm{MJ} / \mathrm{kg}$, respectively. Both volatile matter and heating value of CFW were high as compared to the other biomasses such as coconut husk (Liu \& Han, 2015), coconut shell (Ghani et al., 2010), coconut peat (Lee et al., 2013), rice husk (Natarajan \& Sundaram, 2009), banana stem (Abdullah et al., 2014) and oil palm empty fruit bunches (Shariff et al., 2014).

According to the elemental analysis results, CFW was mainly consisted of 58.33 wt.\% carbon content and 24.65 wt.\% oxygen content. However, it was also contained low percentages of nitrogen and sulphur contents which both were less than $1.40 \mathrm{wt} . \%$. Therefore, low rates of nitrogen oxides and sulphur oxides gases would be released during the pyrolysis process, indicating that CFW was a relatively environmental friendly feedstock for biochar production.

\section{Effect of pyrolysis temperature on biochar yield}

Fig. 3 represents the graph of biochar yield from slow pyrolysis of $\mathrm{CFW}$ at temperature ranged from $350^{\circ} \mathrm{C}$ to $600^{\circ} \mathrm{C}$. The graph showed that the biochar yield was decreased as the terminal temperature of slow pyrolysis was increased. The same trend of results was also found from the previous studies on slow pyrolysis of other biomasses including coconut shell (Sundaram \& Natarajan, 2009), cogon grass (Azduwin et al., 2012), pomegranate seeds (Uçar \& Karagöz, 2009) and mallet wood (Abdullah \& Wu, 2009).

From Fig. 3, the percentage yield of CFWB was decreased by $40.65 \%$, from $23.54 \mathrm{wt} . \%$ to $13.97 \mathrm{wt} \%$ as the terminal temperature was increased from $350^{\circ} \mathrm{C}$ to $600^{\circ} \mathrm{C}$. The biochar yield was rapidly decreased by $27.70 \%$ in the beginning from temperature of $350^{\circ} \mathrm{C}$ to $400^{\circ} \mathrm{C}$. Then, the thermal decomposition of the feedstock was gradually decreased after $400^{\circ} \mathrm{C}$. The biochar yield between $400^{\circ} \mathrm{C}$ to $600^{\circ} \mathrm{C}$ was decreased by $17.92 \%$ from 17.02 wt. $\%$ to 13.97 wt. $\%$. The decrement in biochar yield was due to a greater primary decomposition of the organic feedstock (CFW) at higher pyrolysis temperature (Claoston et al., 2014; Mimmo et al., 2014). It could also be due to the secondary decomposition of biochar residue that involved the charring and devolatilization reactions as the pyrolysis temperature was increased (Claoston et al., 2014). The highest amount of CFWB was produced at pyrolysis temperature of $350^{\circ} \mathrm{C}$ with 23.54 wt.\%. Meanwhile, the lowest biochar yield was 13.97 wt. $\%$ that produced at the pyrolysis temperature of $600^{\circ} \mathrm{C}$.

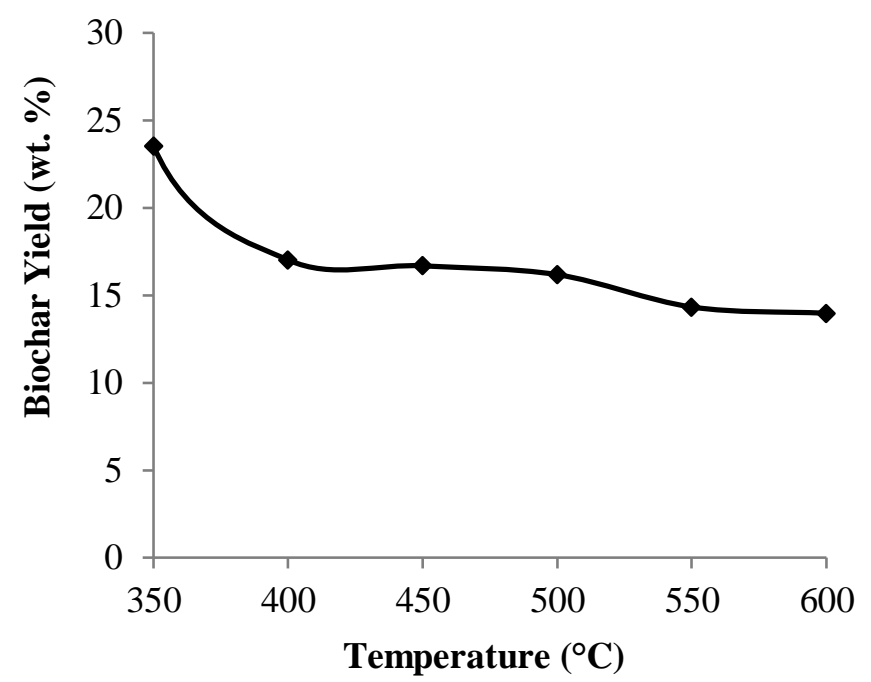

Fig. 3 Biochar yield at different pyrolysis temperature.

\section{Effect of pyrolysis temperature on the composition of biochar}

Table 2 shows the results of proximate and elemental analyses of CFWB as a function of pyrolysis temperature. From the proximate analysis results, the fixed carbon content of biochar was increased considerably with pyrolysis temperature. The same trend of results was also obtained from many pyrolysis studies that used various other types of biomass feedstock such as cassava wastes (Noor et al., 2012), softwood pellets (Mašek et al., 2013), oil palm fronds (Rahman et al., 2014) and fir wood (Suliman et al., 2016). The increment of pyrolysis temperature from $350^{\circ} \mathrm{C}$ to $600^{\circ} \mathrm{C}$ has increased the fixed carbon content of biochar from 45.20 wt.\% to 79.09 wt.\%. The CFWB produced at higher pyrolysis temperature has the potential as a soil carbon sequester. According to Brassard et al. (2016), the fixed carbon would ultimately show the effectiveness of biochar that acted as carbon negative from the environment point of view. Biochar with higher fixed carbon content would exhibit higher effectiveness as a climate change mitigation tool.

More volatile matters in the biochar were forcibly expelled out during pyrolysis at higher temperature (Paethanom \& Yoshikawa, 2012). This explained the substantial decrement of volatile matter of CFWB by $74.67 \%$ from 50.17 wt. $\%$ to 12.71 wt.\% as the pyrolysis temperature was increased from $350^{\circ} \mathrm{C}$ to $600^{\circ} \mathrm{C}$. Values from the volatile matter of biochar could be used to evaluate the quality of biochar as fuels and also to explain the biochar stability as soil application (Lehmann et al., 2011). According to Liu et al. (2013), biochar with high volatile matter content could reduce combustion efficiency and increase pollutant emission when it was directly combusted. Meanwhile, in term of soil application, Brassard et al. (2016) stated that biochar with higher volatile matter might indicate low potential for carbon sequestration.

Pyrolysis temperature did not affect much on moisture and ash content of the biochar product. Based on the proximate analysis results in Table 2, CFWB produced at temperature ranged from $350^{\circ} \mathrm{C}$ to $600^{\circ} \mathrm{C}$ has low moisture and ash content, both were less than $9.00 \mathrm{wt} \%$. Biochar produced from pyrolysis temperature ranged from $350^{\circ} \mathrm{C}$ to $600^{\circ} \mathrm{C}$ was contained of 0.56 wt. $\%$ to 4.27 wt. $\%$ of moisture content while the ash content was ranged from 4.63 wt.\% to 8.19 wt. \%

The comparison of proximate analysis results in Table 1 and Table 2 showed that the fixed carbon contents of all biochars produced at any pyrolysis temperature were much higher compared to the fixed carbon content of its raw feedstock. For example, the CFWB produced at a temperature of $600^{\circ} \mathrm{C}$ was contained of nearly 10 times higher fixed carbon compared to its raw feedstock which only has the 
fixed carbon content of 7.92 wt.\%. Meanwhile, the value of volatile matter in raw feedstock experienced a substantial decline after conversion into biochar. For example, the CFWB produced at temperature of $600^{\circ} \mathrm{C}$ contained $12.71 \mathrm{wt} . \%$ of volatile matter which was only $13.96 \%$ of the volatile matter in its raw feedstock.

Table 2 Proximate analysis, elemental analysis and high heating value of biochar derived at various pyrolysis temperatures.

\begin{tabular}{lcccccc}
\hline $\begin{array}{l}\text { Temperature } \\
\left({ }^{\circ} \mathbf{C}\right)\end{array}$ & $\mathbf{3 5 0}$ & $\mathbf{4 0 0}$ & $\mathbf{4 5 0}$ & $\mathbf{5 0 0}$ & $\mathbf{5 5 0}$ & $\mathbf{6 0 0}$ \\
\hline $\begin{array}{l}\text { Proximate } \\
\text { analysis, }\end{array}$ & & & & & & \\
(wt.\%) & 0.56 & 1.56 & 3.33 & 3.40 & 4.27 & 2.36 \\
Moisture & 50.17 & 24.82 & 17.60 & 15.79 & 12.99 & 12.71 \\
Volatile matter & 4.63 & 6.27 & 7.96 & 7.97 & 8.15 & 8.19 \\
Ash content & 45.20 & 68.91 & 74.44 & 76.24 & 78.86 & 79.09 \\
Fixed carbon & & & & & & \\
& & & & & & \\
Elemental & & & & & & \\
analysis, & & & & & & \\
(wt.\%) & 72.70 & 78.37 & 81.09 & 82.65 & 83.07 & 83.25 \\
Carbon, C & 10.04 & 5.72 & 2.84 & 2.60 & 1.99 & 1.45 \\
Hydrogen, H & 2.15 & 2.67 & 2.67 & 2.76 & 2.53 & 2.98 \\
Nitrogen, N & 1.25 & 0.15 & 1.23 & 0.20 & 1.13 & 1.33 \\
Sulphur, S & 13.86 & 13.09 & 12.17 & 11.79 & 11.28 & 10.99 \\
Oxygen, O & & & & & & \\
& 33.95 & 29.39 & 28.52 & 28.32 & 27.99 & 27.48 \\
High heating & & & & & & \\
value, (MJ/kg) & & & & & & \\
\hline
\end{tabular}

The elemental analysis results in Table 2 showed the percentage of carbon content of CFWB was increased along with the pyrolysis temperature. It could be seen that as the pyrolysis temperature was raised from $350^{\circ} \mathrm{C}$ to $600^{\circ} \mathrm{C}$, the carbon content of biochar was increased from $72.70 \mathrm{wt} . \%$ to $83.25 \mathrm{wt} . \%$. According to Novak et al. (2009), the increment of carbon content in biochar at higher pyrolysis temperature was actually due to the removal of the volatile compounds. This was also explained the substantially decrement of the volatile matter content in biochar as the pyrolysis temperature was increased from $350^{\circ} \mathrm{C}$ to $600^{\circ} \mathrm{C}$.

Higher pyrolysis temperature produced biochar with lower hydrogen and oxygen content. Table 2 showed that the biochars produced from $350^{\circ} \mathrm{C}$ to $600^{\circ} \mathrm{C}$ experienced significant decrease in hydrogen content by $85.56 \%$ from 10.04 wt. $\%$ to $1.45 \mathrm{wt} . \%$, while the oxygen content was decreased by $20.71 \%$ from 13.86 wt. $\%$ to 10.99 wt.\%. Mašek et al. (2013) stated that as the pyrolysis temperature was raised, more oxygen and hydrogen elements were released in the gaseous and vapour phases, thus decreasing the percentage of both oxygen and hydrogen contents in the biochar.

Biochar with lower oxygen and volatile matter could potentially be a good source of solid fuel. The comparison of oxygen and volatile matter results in Table 1 and Table 2 showed that all the biochar produced at any pyrolysis temperature contained lower percentages of oxygen and volatile matter compared to its raw feedstock. According to Liu et al. (2013), the combination of low oxygen and volatile matter contents of biochars could potentially reduce the release of inorganic vapours during combustion, compared to its raw feedstock (Liu et al., 2013).

Table 2 also showed that both the nitrogen and sulphur contents in biochars did not show any significant difference with increasing pyrolysis temperature. However, both the nitrogen and sulphur contents of CFWB produced at any studied temperature were all low which less than 3.00 wt.\%.

High heating value or calorific value is a major quality index for fuels which defines its energy content (Sukiran et al., 2011). Results in Table 2 showed that biochar produced at higher pyrolysis temperature contained lower heating value. Heating value of biochar was decreased from $33.95 \mathrm{MJ} / \mathrm{kg}$ to $27.48 \mathrm{MJ} / \mathrm{kg}$ as the pyrolysis temperature was increased from $350^{\circ} \mathrm{C}$ to $600^{\circ} \mathrm{C}$. The results comparison in Table 1 and Table 2 showed that, biochar produced at $350^{\circ} \mathrm{C}$ and $400^{\circ} \mathrm{C}$ contained higher heating value compared to its raw feedstock. Biochar produced at $350^{\circ} \mathrm{C}$ contained the highest heating value of $33.95 \mathrm{MJ} / \mathrm{kg}$ which was $17.68 \%$ higher than the heating value of its raw feedstock. This showed that pyrolysis at lower temperature could increase the quality of CFW for fuel application.

\section{Effect of pyrolysis temperature on the physical properties of biochar}

Fig. 4 showed that higher pyrolysis temperature would increase the BET surface area of CFW. The same results could also be found in the studies done by using maize (Wang et al., 2015), woods (Suliman et al., 2016), and wheat straw (Zhao et al., 2014) as pyrolysis feedstock. As the pyrolysis temperature was increased from $350^{\circ} \mathrm{C}$ to $500^{\circ} \mathrm{C}$, the surface area of CFWB was slowly increased from 0.3971 $\mathrm{m}^{2} / \mathrm{g}$ to $0.6619 \mathrm{~m}^{2} / \mathrm{g}$. Then, from temperature $500^{\circ} \mathrm{C}$ to $600^{\circ} \mathrm{C}$, the surface area was rapidly increased by more than 5 folds from 0.6619 $\mathrm{m}^{2} / \mathrm{g}$ to $3.4486 \mathrm{~m}^{2} / \mathrm{g}$. According to Wang et al. (2013), the increment of surface area could be due to the loss of organic compound or enhanced devolatilization which created void within the biochar matrix. As we could see from Fig.5 (b), the two arrows showed the development of deep and large pores in biochar that produced at $600^{\circ} \mathrm{C}$ which caused the increment of its surface area.

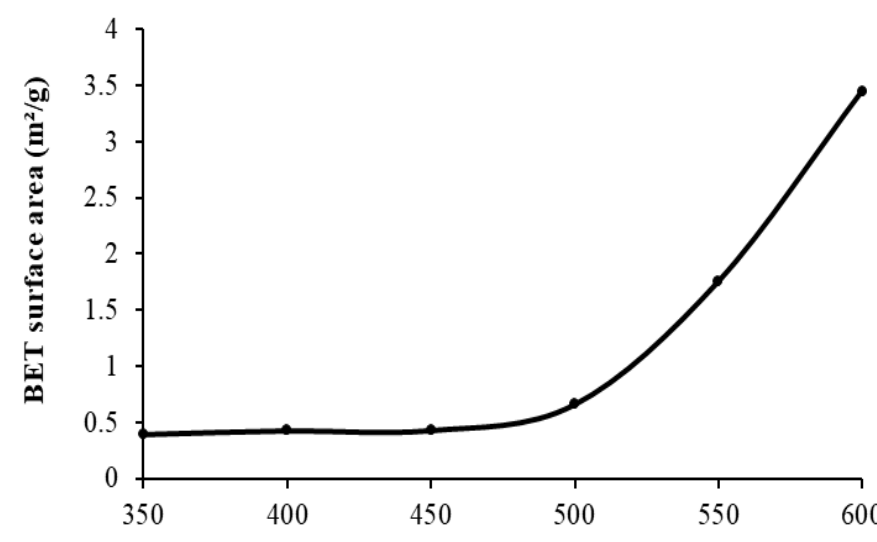

Temperature $\left({ }^{\circ} \mathrm{C}\right)$

Fig. 4 Effect of pyrolysis temperature on BET surface area of CFWB.

The comparison of SEM images of raw CFW in Fig. 5 (a) with the biochars in Fig. 5 (b) and Fig. 5 (c) was clearly showed that the cell walls had undergone structure modification after conversion into biochar. This was due to the heat from the pyrolysis process that changed the microstructure of the raw feedstock. In Fig. 5 (a), the cell walls of the raw CFW were appeared to be uniform and did not have any clear pores. Meanwhile, the SEM image of biochar produced at $400^{\circ} \mathrm{C}$ in Fig. 5 (b) showed more obvious pores and the cell walls that were partially reconstructed and caused the shape to become enlarged. As the temperature was increased further to $600^{\circ} \mathrm{C}$, the pores of CFWB in Fig. 5 (c) were appeared to be larger and deeper. The cell walls were also shrunk, broken and totally reconstructed.

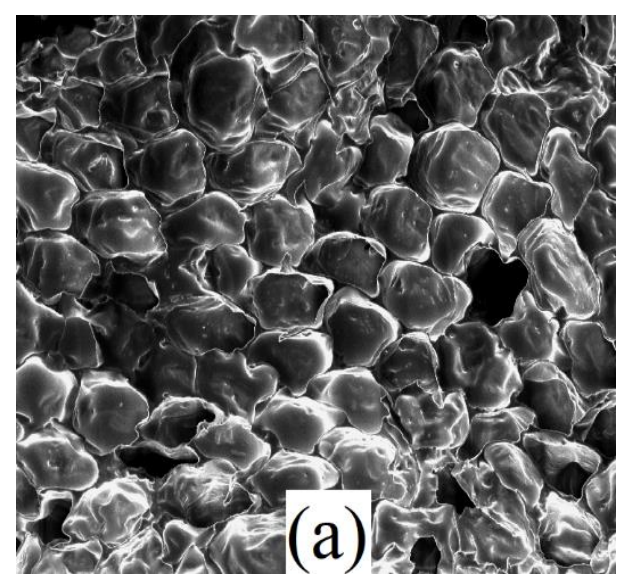



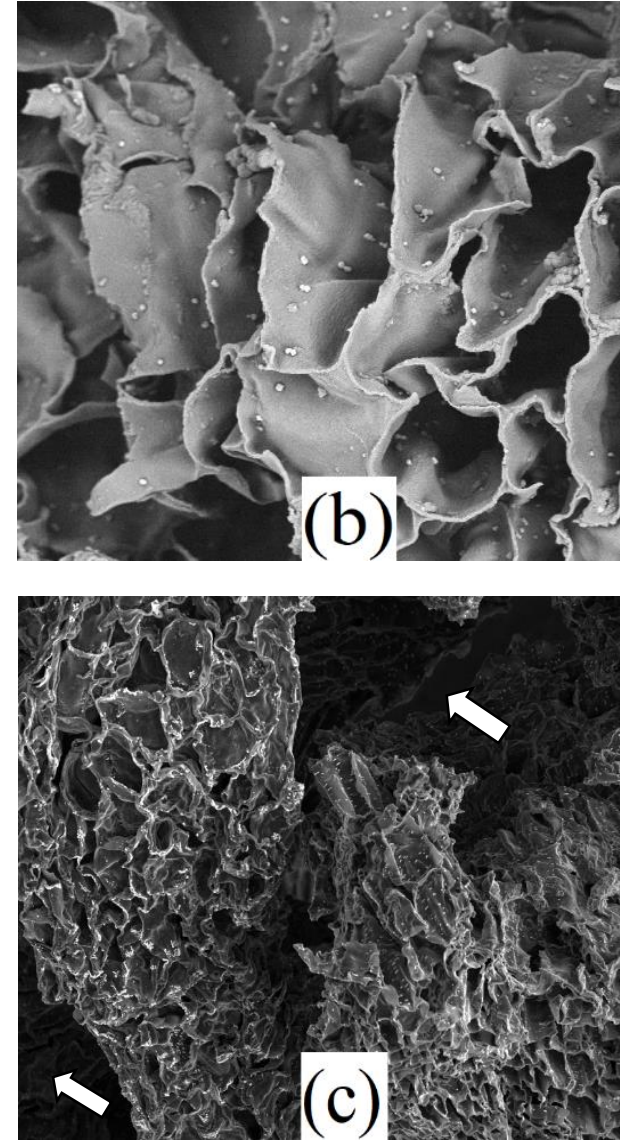

Fig. 5 SEM images of (a) CFW, (b) CFWB at $400^{\circ} \mathrm{C}$ and (c) CFWB at $600^{\circ} \mathrm{C}$, all at magnification of $500 \mathrm{X}$.

\section{CONCLUSION}

The findings suggested that pyrolysis temperature could affect the chemical and physical properties of CFWB. Higher pyrolysis temperature would reduce the percentage yield of biochar, increase the fixed carbon content and decrease its volatile matter. The increment of pyrolysis temperature from $350^{\circ} \mathrm{C}$ to $600^{\circ} \mathrm{C}$ has highly increased the BET surface area of the biochar by more than 8 times. This suggested that CFWB produced at higher pyrolysis temperature has the potential as soil amendment. CFBW produced at high temperatures might possess a higher potential for carbon sequestration when being applied to the soil as compared to that obtained at low temperatures as it contained higher fixed carbon content. Lower pyrolysis temperature would produce higher percentage yield of CFWB with higher heating value. This showed a promising alternative for production of a solid fuel from $\mathrm{CFW}$, which could potentially be combusted in existing coal-fired plants.

\section{ACKNOWLEDGEMENT}

The financial support from Ministry of Higher Education Malaysia under the Fundamental Research Grant Scheme 203/PFIZIK/6711410 and the technical support from Universiti Sains Malaysia were gratefully acknowledged. The authors also would like to thank Madam Hamidah Ahmad as the owner of the coconut milk supplier for her kindness to supply the CFW for this research.

\section{REFERENCES}

Abdullah, H., \& Wu, H. (2009). Biochar as a fuel: 1. Properties and grindability of biochars produced from the pyrolysis of mallee wood under slow-heating conditions. Energy \& Fuels, 23(8), 4174-4181.

Abdullah, N., Sulaiman, F., Miskam, M. A., \& Taib, R. M. (2014). Characterization of banana (Musa spp.) pseudo-stem and fruit-bunch-stem as a potential renewable energy resource. International Journal of Energy and Power Engineering, 8(8), 815-819.

APCC. (2017). Production of coconuts in whole nuts, 2010 - 2014. Retrieved from http://www.apccsec.org/apccsec/statistic-11.html

Azduwin, K., Ridzuan, M. J. M., Hafis, S. M., \& T.A, T. A. (2012). Slow pyrolysis of imperata cylindrica in a fixed bed reactor. International Journal of Biological, Ecological and Environmental Sciences, 1(5), $176-180$.

Balat, M., Balat, M., Kirtay, E., \& Balat, H. (2009). Main routes for the thermo-conversion of biomass into fuels and chemicals. Part 1: Pyrolysis systems. Energy Conversion and Management, 50(12), 3147-3157.

Bazargan, A., Rough, S. L., \& McKay, G. (2014). Compaction of palm kernel shell biochars for application as solid fuel. Biomass and Bioenergy, 70, 489-497.

Brassard, P., Godbout, S., \& Raghavan, V. (2016). Soil biochar amendment as a climate change mitigation tool: Key parameters and mechanisms involved. Journal of Environmental Management, 181, 484-497.

Claoston, N., Samsuri, A. W., Husni, M. H. A., \& Amran, M. S. M. (2014). Effects of pyrolysis temperature on the physicochemical properties of empty fruit bunch and rice husk biochars. Waste Management \& Research, 33(3), 275-283.

Deris, R. R. R., Sulaiman, M. R., Darus, F. M., Mahmud, M. S., \& Bakar, N. A. (2006). Pyrolysis of oil palm trunk (OPT). Paper presented at the 20th Symposium of Malaysian Chemical Engineers, UiTM Shah Alam, Selangor, Malaysia.

DOSM. (2016). Press release supply and utilization accounts selected agricultural commodities, Malaysia 2011-2015 [Press release]. Retrieved from https://www.dosm.gov.my/v1/ index.php?r=column/cthemeByCat\& cat=164\&bul_id=L1FGWIV1SWx5VWIyZUpCWjB4NzU1UT09\&menu _id=Z0VTZGU1UHBUT1VJMFlpaXRRR0xpdz09

Downie, A., Crosky, A., \& Munroe, P. (2009). Chapter 2: Physical properties of biochar. In J. Lehmann \& S. Joseph (Eds.), Biochar for Environmental Management: Science and Technology (1st ed., pp. 14-32). UK and USA: Earthscan.

Ghani, W. A. W. A. K., Abdullah, M. S. F., Matori, K. A., Alias, A. B., \& silva, G. d. (2010). Physical and thermochemical characterization of malaysian biomass ashes. Journal of the Institution of Engineers, Malaysia, 71(3), 9-18.

Gheorghe, C., Mărculescu, C., Badea, A., \& Apostol, T. (2010). Pyrolysis parameters influencing the bio-char generation from wooden biomass. U.P.B. Science Bulletin, Series C: Electrical Engineering, 72(1), 30-38.

Hunt, J., DuPonte, M., Sato, D., \& Kawabata, A. (2010). The basics of biochar: A natural soil amendment. SCM-30. Retrieved from http://www.ctahr.hawaii.edu/oc/freepubs/pdf/SCM-30.pdf

IBI. (2016). Climate change and biochar. Retrieved from http://www.biocharinternational.org/biochar/carbon

Jahirul, M. I., Rasul, M. G., Chowdhury, A. A., \& Ashwath, N. (2012). Biofuels production through biomass pyrolysis - A technological review. Energies, 5, 4952-5001.

Lee, Y., Park, J., Ryu, C., Gang, K. S., Yang, W., Park, Y. K., \& Hyun, S. (2013). Comparison of biochar properties from biomass residues produced by slow pyrolysis at $500^{\circ} \mathrm{C}$. Bioresource Technology, 148, 196-201.

Lehmann, J. (2007). Bio-energy in the black. Frontiers in Ecology and the Environment, 5(7), 381-387.

Lehmann, J., Gaunt, J., \& Rondon, M. (2006). Bio-char sequestration in terrestrial ecosystems - A review. Mitigation and Adaptation Strategies for Global Change, 11, 403-427.

Lehmann, J., Rillig, M. C., Thies, J., Masiello, C. A., Hockaday, W. C., \& Crowley, D. (2011). Biochar effects on soil biota - A review. Soil Biology and Biochemistry, 43(9), 1812-1836.

Liu, Z., \& Han, G. (2015). Production of solid fuel biochar from waste biomass by low temperature pyrolysis. Fuel, 158, 159-165.

Liu, Z., Quek, A., Kent Hoekman, S., \& Balasubramanian, R. (2013). Production of solid biochar fuel from waste biomass by hydrothermal carbonization. Fuel, 103, 943-949.

Mašek, O., Brownsort, P., Cross, A., \& Sohi, S. (2013). Influence of production conditions on the yield and environmental stability of biochar. Fuel, 103, 151-155

Mimmo, T., Panzacchi, P., Baratieri, M., Davies, C. A., \& Tonon, G. (2014). Effect of pyrolysis temperature on miscanthus (Miscanthus giganteus) biochar physical, chemical and functional properties. Biomass and Bioenergy, 62, 149-157.

Mohan, D., Sarswat, A., Ok, Y. S., \& Pittman Jr, C. U. (2014). Organic and inorganic contaminants removal from water with biochar, a renewable, low cost and sustainable adsorbent - A critical review. Bioresource Technology, 160, 191-202.

Natarajan, E., \& Sundaram, E. G. (2009). Pyrolysis of rice husk in a fixed bed reactor. World Academy of Science, Engineering and Technology, 56, 504-508. 
Ng, S. P., Tan, C. P., Lai, O. M., Long, K., \& Mirhosseini, H. (2010). Extraction and characterization of dietary fiber from coconut residue. Journal of Food, Agriculture \& Environment, 8(2), 172-177.

Noor, N. M., Shariff, A., \& Abdullah, N. (2012). Slow pyrolysis of cassava wastes for biochar production and characterization. Iranica Journal of Energy \& Environment 3 (Special Issue on Environmental Technology), 60-65.

Novak, J. M., Lima, I., Xing, B., Gaskin, J. W., Steiner, C., Das, K. C., Schomberg, H. (2009). Characterization of designer biochar produced at different temperatures and their effects on a loamy sand. Annals of Environmental Science, 3, 196-206.

Odesola, I. F., \& Owoseni, T. A. (2010). Small scale biochar production technologies: A review. Journal of Emerging Trends in Engineering and Applied Sciences (JETEAS), 1(2), 151-156.

Raghavarao, K. S. M. S., Raghavendra, S. N., \& Rastogi, N. K. (2008). Potential of coconut dietary fiber. Indian Coconut Journal, 51(6), 2-7.

Rahman, A. A., Abdullah, N., \& Sulaiman, F. (2014). Temperature effect on the characterization of pyrolysis products from oil palm fronds. Advances in Energy Engineering (AEE), 2(1), 14-21

Shariff, A., Aziz, N. S. M., \& Abdullah, N. (2014). Slow pyrolysis of oil palm empty fruit bunches for biochar production and characterisation. Journal of Physical Science, 25(2), 97-112.

Sukiran, M. A., Kheang, L. S., Bakar, N. A., \& May, C. Y. (2011). Production and characterization of bio-char from the pyrolysis of empty fruit bunches. American Journal of Applied Sciences, 8(10), 984-988.

Sulaiman, S., Abdul Aziz, A. R., \& Kheireddine Aroua, M. (2013). Optimization and modeling of extraction of solid coconut waste oil Journal of Food Engineering, 114(2), 228-234.

Sulaiman, S., R., A. A. A., \& Aroua, M. K. (2014). Biodiesel production from solid coconut waste. Advances in Environmental Biology, 8(3), 781-786.

Suliman, W., Harsh, J. B., Abu-Lail, N. I., Fortuna, A. M., Dallmeyer, I., \& Garcia Perez, M. (2016). Influence of feedstock source and pyrolysis temperature on biochar bulk and surface properties. Biomass and Bioenergy, 84, 37-48.

Sundaram, E. G., \& Natarajan, E. (2009). Pyrolysis of coconut shell: An experimental investigation. The Journal of Engineering Research, 6(2), 33-39.

Uçar, S., \& Karagöz, S. (2009). The slow pyrolysis of pomegranate seeds: The effect of temperature on the product yields and bio-oil properties. Journal of Analytical and Applied Pyrolysis, 84(2), 151-156.

Verheijen, F. G. A., Jeffery, S., Bastos, A. C., Velde, M. v. d., \& Diafas, I. (2009). Biochar application to soils - A critical scientific review of effects on soil properties, processes and functions. Retrieved from http://www.et2050.eu/et2050_library/ docs/tech/environment/Biochar.pdf

Verma, M., Godbout, S., Brar, S. K., Solomatnikova, O., Lemay, S. P., \& Larouche, J. P. (2012). Biofuels production from biomass by thermochemical conversion technologies. International Journal of Chemical Engineering, 2012, 1-18.

Vetayasuporn, S. (2007). The feasibility of using coconut residue as a substrate for oyster mushroom cultivation. Biotechnology, 6(4), 578-582.

Vieweg. (1984). Heat, fire and stoves. In: Fuel-Saving Cook Stoves. Retrieved from http://www.fastonline.org/CD3WD_40/CD3WD/ APPRTECH/G14F UE/EN/B774_9.HTM

Wang, X., Zhou, W., Liang, G., Song, D., \& Zhang, X. (2015). Characteristics of maize biochar with different pyrolysis temperatures and its effects on organic carbon, nitrogen and enzymatic activities after addition to fluvoaquic soil. Science of The Total Environment, 538, 137-144.

Zajec, L. (2009). Slow Pyrolysis in a rotary kiln reactor: Optimization and experiments. (Master), University of Iceland and University of Akureyri. Retrieved from http://skemman.is/stream/get/1946/7005/17751/1/ Luka_Zajec.pdf

Zhao, L., Zheng, W., \& Cao, X. (2014). Distribution and evolution of organic matter phases during biochar formation and their importance in carbon loss and pore structure. Chemical Engineering Journal, 250, 240-247. 